\title{
Mites Inhabiting Date Palm Trees and their Dynamics with Reference to Reproduction and Life Table Parameters of Raoiella indica Hirst (Tenuipalpidae) at Three Different Temperatures
}

\author{
Amira E. Mesbah \\ Plant Protection Research Institute, A.R.C., Dokki, Egypt
}

\begin{abstract}
Twenty six mite species in 22 genera and 17 families were collected from date palm trees in two Egyptian Governorates during 2012 and 2013. Population dynamics of mites associated with date palm leaves were reported. Biological aspects of Raoiella indica on leaves of Phoenix dactylifera $\mathrm{L}$. were studied under laboratory conditions of 15,20 and $25 \pm 2^{\circ} \mathrm{C}$ and $60 \pm 5 \% \mathrm{RH}$. Feeding at $15 \pm 2^{\circ} \mathrm{C}$ significantly prolonged predator longevity (42.38 \& 37.26 days), for females $\&$ males, respectively and caused a higher rate of fertility averaged 96 egg through an average oviposition period of 28 day. Life table parameters showed that the highest intrinsic rate of natural increase $\left(\mathrm{r}_{\mathrm{m}}\right)$ was reached as 0.149 at $20^{\circ} \mathrm{C}$, respectively. This range of temperature was considered as the optimal range for this mite. Lower $r_{m}$ value as 0.115 was obtained at $15^{\circ} \mathrm{C}$. Time for population doubling was determined as $6.05,4.65$ and 4.83 at studied temperatures, respectively.
\end{abstract}

Key Words: Date palm trees, Raoiella indica, Life table parameters, Mite populations.

\section{INTRODUCTION}

Pests attacking date palm trees are key factors affecting to great extent the degradation of both quality and quantity of date yield as well as longevity and survivor of perennial tree. In Egypt some studies were carried out by Sallam and Yassin (2005), Sallam et al. (2007) and El-Sanady and Mohamed (2013) to study incidence and population dynamics of certain mite species on date palm in different governorates of Egypt.

In 2004, Raoiella indica (Acari: Tenuipalpidea) was reported for the first time in the new world. This species has spread throughout the Neotropics and has gained economic importance, especially because of the damage it inflicts on coconut palms (Cocos nucifera), other palm species (Areca catechu, Phoenix dactylifera), and bananas, all important sources of nutrition and income for people inhabiting the tropical world, Kane and Ochoa (2006).

Raoiella indica (Hirst) may represent a threat to the ornamental palms industry and to date palm and banana crops. It is commonly known as the red palm mite, leaflet false spider mite, frond crimson mite, or scarlet mite, important pest of date palms and other palm species, as well as a pest of bananas, beans, in different parts of the world (Pena et al. 2006).

The main objective of this study was to shed light on distribution, some ecological aspects and population dynamics of mites inhabiting date palm trees all over Sharkia and Giza Governorates, Egypt to review all available information about mites that have been reported in association with $R$. indica and explain importance of biological control to manage population of phytophagous mites. Biological aspects and life table parameters were conducted to design a better strategy for decreasing the population of $R$.indica pest attacking date palm trees.

\section{MATERIALS AND METHODS}

\section{I-Ecological-Studies:-}

Mites inhabiting date palm (leaves, fruits and soil) were surveyed during two successive years, 2012 and 2013. Samples were collected from two governorates, Giza and Sharkia (Belbies, Enshass, Abou Hammad, Hehia,Zagazig, Minea El-Kamh). Samples were sent to laboratory at Sharkia for mites count.

\section{II-Population Dynamics:-}

Monthly samples of 40 leaves each for population dynamics were collected from the two locations (i.e. Sharkia and Giza). Population densities of phytophagous mites were estimated as mites present on one square inch $(=2.6 \mathrm{~cm})$ of the upper leaf surface while predacious mites were also counted by examining both leaf surfaces.

\section{III-Biological-studies and life table parameters of Raoiella indica :-}

This study was conducted at three constant temperatures of 15,20 and $25 \pm 2{ }^{\circ} \mathrm{C}$ and $60 \% \mathrm{RH}$. Stock culture was obtained from heavily infested date palm leaves obtained from Plant-ProtectionResearch-Institute-Dokki, Giza. The duration of developmental stages was studied on excised leaf disc in the laboratory. Before rearing mites, it was ensured that all unwanted organisms were removed from leaves by thoroughly brushing the leaves and by examining under stereo-microscope. Square leaf 
discs, each $3 \mathrm{~cm}$ in diameter were placed on a cotton wool bed in Petri dishes $(5 \times 6 \mathrm{~cm})$ with the lower surface upwards, the cotton bed was soaked with water twice daily so that the discs remained fresh.

Two $R$. indica adult females were transferred from the stock culture to each disc for laying eggs. After 36 days, eggs were seen on each of the excised leaves, and thus 40-80 freshly laid eggs were available and all belonged to the same age. Observations were recorded until larvae hatched. Each larva was kept separately on a disc for recording duration of different biological aspects. Old leaves were replaced with fresh ones when needed. For determining the fecundity of unfertilized females, the female deutonymphs, before molting to adults were kept separately without allowing them to mate. For determining the fecundity of fertilized females, each female deutonymph was kept with a male. The number of laid eggs was counted till end of female oviposition period.

\section{IIII-Statistical analysis}

Data were subjected to the statistical analysis. Monthly average minimum and maximum temperatures $\left({ }^{\circ} \mathrm{C}\right)$ and average relative humidity (R.H\%) prevailing in the area during the study were obtained from site http://www.wunderground.com

\section{RESULTS AND DISCUSSION}

\section{I-Ecological-Studies:-}

During this study, 26 mite species in 22 genera and 17 families were collected. These mites were classified according to their feeding habits.

\section{(1)Phytophagous mites}

Members of the families Tetranychidae, Tenuipalpidae and Phytoptidae are plant feeders of considerable economic importance. Of these, six mite species belonging to five genera in three families were recorded (Table 1).

Family- Tetranychidae Donnadieu: The date palm leaf brown mite, Eutetranychus orientalis (Klein) causes injury to leaves by feeding on the upper leaf surface. It was recorded from Hehia-district at Sharkia in high number on date palm leaves.

Family Tenuipalpidae (Berlese): The incidence of date palm mite, Raoiella indica (Hirst) was recorded in high numbers on leaves at Dokki-Giza.

Brevipalpus obvatus (Donnadieu) infested leaves and fruits preferring the lower surface around the midrib. Injured areas become pale then change to rusty brown at heavy infestation and brownish areas appear on date fruits. This species was recorded in high number on leaves of date palm in Minea El-Kamh.

\section{Brevipalpus phoenicis (Geijskes)}

It was recorded in low numbers infesting the lower surface of leaves and the fruits in moderate numbers.

Phyllotetranychus aegyptiacus (Sayed) was recorded in moderate number on leaves and in low numbers in fruits at Garden of the Faculty of Agricultural-CairoUniversity Giza.

\section{Family: Phytoptidae Murray}

The mite, Mackiella phoenicis (Keifer) was recorded in moderate numbers on inner fronds, causing malformation of old fronds, then the leaves became dry and fell off.

\section{(2) Predaceous mites}

Twelve predaceous mite species of ten genera in eight families were collected (Table 2).

Family - Phytoseiidae (Berlese) Members of the family Phytoseiidae were common and expected to be found associated with both mites and insects infestations. Phytoseiid mites are important mortality factors of $R$. indica.

Amblyseius hutu (Pritchard \&Baker) was recorded in high numbers on leaves and fruits in all areas of Sharkia governorate expecting to play an important role in controlling acarine pests.

A. swirsikii Athias -Henriot was found on leaves and fruits in moderate numbers in Giza.

A. cydnodactylon Shehata and Zaher was found in moderate numbers on leaves in Giza and Sharkia.

Family- Stigmaeidae Oudemans are potential predators of various phytophagous mite species.

Agistemus exsertus (Gonzalez) seemed to be the most important stigmaeid mite on date palm trees occurring in all areas of the study. It was recorded in moderate numbers on leaves in Giza and Sharkia.

Family Scutacridae : Scutacrus sp. only one female was found associated with fallen leaf.

Family Bdellidae: Spinbdella cortices (Ewing) was found on leaves in moderate numbers at Giza.

Family Cunaxidae: Pulaeus glebulentus (Den Heyer) was found on leaves at Sharkia in low numbers.

Family Smarididae: only one mite, Samaris cristatus (Gray) found on soil.

Family Macrochelidae: Macrocheles glaber (Müller) was found on fallen date (soil) in moderate numbers in both Giza \& Sharkia.

Family Cheyletidae: Cheletogens ornatus (Canestrini \&Fanzago) was found combined with phytophagous mites and scale insects infestation. It 
Table (1) Incidence of phytophagous mites associated with date palm trees

\begin{tabular}{|c|c|c|c|}
\hline Families & Species & Localities & Habitat and abundance \\
\hline Tetranychidae & Eutetranychus orientalis (Klein) & Sharkia & Leaves +++(high) \\
\hline \multirow[t]{4}{*}{ Tenuipalpidae } & Raoiella indica (Hirst) & Giza & leaves +++(high) \\
\hline & Brevipalpus obovatus Donnadieu & Sharkia & Leaves+++ (high)\& Fruits +(low) \\
\hline & B. pheonicis (Geijskes) & Sharkia & Fruits ++ (moderate) \&Leaves $+($ low $)$ \\
\hline & Phyllotetranychus aegyptiacus (Sayed) & Giza & Leaves++(moderate) \& Fruits $+($ low $)$ \\
\hline Phytoptidae & Mackiella phoenicis (Keifer) & Giza & Leaves $++($ moderate $)$ \\
\hline
\end{tabular}

Table (2) Incidance of predaceous mites associated with date palm trees

\begin{tabular}{|c|c|c|c|}
\hline Families & Species & Localities & Habitat and abundance \\
\hline \multirow[t]{3}{*}{ Phytoseiidae } & Amblyseius hutu (Pritchard\&Baker) & Sharkia(All areas) & Leaves+++(High ) \& Fruits \\
\hline & A.swirsikii (Athias - Henrio) & Giza & Leaves \& Fruits (moderate)++ \\
\hline & A.cydnodactylon(Shehata and Zaher) & Giza \& Sharkia & Leaves (Moderate)++ \\
\hline Bdellidae & Spinibdella cortices (Ewing) & Giza & Leaves(Moderate)++ \\
\hline Cunaxidae & Pulaeus glebulentus (Den Heyer) & Sharkia & Leaves(low)+ \\
\hline Macrochelidae & Macrocheles glaber (Müller) & Giza \& Sharkia & Fallon date (moderate)++ \\
\hline Stigmaeidae & Agistemus exsertus (Gonzalez) & Giza \& Sharkia & Leaves(Moderate)++ \\
\hline Scutacridae & Scutacrus $s p$ & Sharkia & (Fallon date) + one female \\
\hline Smarididae & Samaris cristatus (Gray) & Sharkia & (Fallon date ) (low)+ \\
\hline \multirow[t]{3}{*}{ Cheyletidae } & Cheletogens ornatus (Canestrini \&Fanzago) & Giza & Leaves+++ (high) \\
\hline & Hemicheyletia bakeri (Ehara) & Sharkia & Leaves (low)+ \\
\hline & Eutogens africaus (Wafaa\&Soliman) & Giza \& Sharkia & Leaves(low) + \\
\hline
\end{tabular}

Table (3) Incidence of mites of miscellaneous feeding habits associated with date palm trees

\begin{tabular}{|c|c|c|c|}
\hline Family & Species & Area & Habitat and abundance \\
\hline Tarsonemidae & $\begin{array}{l}\text { Tarsonemus stifer (Ewing) \& T. gladifer } \\
\text { (Mahunka) \& Stenotarsonemus spirifix (March) }\end{array}$ & Giza\&Sharkia & Leaves (high)+++ \\
\hline Tydeidae & Orthotydeus californicus (Banks) & Giza\&Sharkia & Leaves (moderate)++ \\
\hline Acaridae & Tyrophagous putrescentiae ( Schrank) & Sharkia & Leaves (low) + Fallon date (moderate)++ \\
\hline Glycyphagidae & Blomia freemani (Hughes) & Sharkia & Fallon date $+($ low $)$ \\
\hline Oppiidae & Oppia sticta(Popp) & Giza & Fallon date $+($ low $)$ \\
\hline Oribatulidae & Zygoribtula $s p$ & Sharkia & Fallon date + (low) \\
\hline
\end{tabular}

Table (4): Correlation coefficient between, predaceous mites, temperature, relative humidity and phytophagous mite populations in Sharkia Governorate from Apr. 2012 till Mar. 2014

\begin{tabular}{|c|c|c|c|c|c|c|}
\hline \multirow{2}{*}{$\begin{array}{l}\text { Correlation } \\
\text { Coefficient } \\
\text { values }(r)\end{array}$} & \multicolumn{3}{|c|}{ First year } & \multicolumn{3}{|c|}{ Second year } \\
\hline & R. indica & B. pheonicis & $\begin{array}{l}\text { Crawlers of } \\
\text { Scale insect }\end{array}$ & R. indica & B. pheonicis & $\begin{array}{l}\text { Crawlers of } \\
\text { Scale insect }\end{array}$ \\
\hline Phytoseiidae & $0.005 \mathrm{n} . \mathrm{s}$ & $0.873 * * *$ & $0.921 * * *$ & 0.182 n.s & 0.115 n.s & $0.552 *$ \\
\hline Cheyletidae & $0.899 * * *$ & $0.0438 \mathrm{n} . \mathrm{s}$ & $0.530 *$ & $0.610 *$ & $0.132 \mathrm{n} . \mathrm{s}$ & $0.756 * *$ \\
\hline Stigmaeidae & $0.851 * * *$ & 0.157 n.s & 0.454 n.s & 0.464 n.s & 0.299 n.s & $0.877 * * *$ \\
\hline Max.T. & $0.802 * *$ & $0.645 *$ & 0.197 n.s & $0.897 * * *$ & $0.689^{*}$ & 0.327 n.s \\
\hline Min.T. & $0.722 * *$ & $0.796 * *$ & $0.338 \mathrm{n} . \mathrm{s}$ & $0.843 * * *$ & $0.774 * *$ & 0.104 n.s \\
\hline R.H\% & $0.689 *$ & $0.256 \mathrm{n} . \mathrm{s}$ & $0.774 * *$ & 0.442 n.s & $0.109 \mathrm{n} . \mathrm{s}$ & $0.176 \mathrm{n} . \mathrm{s}$ \\
\hline
\end{tabular}

Table (5):-Correlation coefficient between predaceous mites ,temperature, relative humidity and phytophagous mite populations in Giza Governorate from Apr. 2012 till Mar. 2014

\begin{tabular}{|c|c|c|c|c|c|c|}
\hline \multirow{2}{*}{$\begin{array}{c}\text { Correlation coefficient } \\
\text { values (r) }\end{array}$} & \multicolumn{3}{|c|}{ First year } & \multicolumn{3}{|c|}{ Second year } \\
\hline & R. indica & B. pheonicis & Crawlers of Scale insect & R. indica & B. pheonicis & Crawlers of Scale insect \\
\hline Phytoseiidae & $0.836 * * *$ & $0.826 * * *$ & $0.335 \mathrm{n} . \mathrm{s}$ & $0.641^{*}$ & $0.333 n . s$ & $0.627 *$ \\
\hline Cheyletidae & $0.919 * * *$ & $0.759 * *$ & $0.091 \mathrm{n} . \mathrm{s}$ & $0.932 * * *$ & $0.127 \mathrm{n} . \mathrm{s}$ & $0.953 * * *$ \\
\hline Stigmaeidae & $0.868 * * *$ & $0.795 * * *$ & $0.056 \mathrm{n} . \mathrm{s}$ & $0.741 * *$ & $0.128 \mathrm{n} . \mathrm{s}$ & $0.835 * * *$ \\
\hline Max.T. & $0.747 * *$ & $0.687 *$ & $0.212 \mathrm{n} . \mathrm{s}$ & $0.527 *$ & $0.019 \mathrm{n} . \mathrm{s}$ & $0.770 * *$ \\
\hline Min.T. & $0.651 *$ & $0.576^{*}$ & $0.364 \mathrm{n} . \mathrm{s}$ & $0.039 * * *$ & $0.220 \mathrm{n} . \mathrm{s}$ & $0.954 * * *$ \\
\hline R.H\% & 0.439 n.s & $0.566^{*}$ & $0.741 * *$ & $0.229 \mathrm{n} . \mathrm{s}$ & $=0.068$ n.s & 0.422 n.s \\
\hline
\end{tabular}


Table (6): Developmental durations in days \pm S.D. of R.indica when reared on three different temps and $60 \pm 5 \%$ R.H:

\begin{tabular}{|c|c|c|c|c|c|c|c|}
\hline \multirow{2}{*}{$\begin{array}{c}\text { Temperature } \\
\left({ }^{\circ} \mathrm{C}\right)\end{array}$} & \multirow{2}{*}{$\begin{array}{l}\text { Incubation } \\
\text { Period }\end{array}$} & \multicolumn{3}{|c|}{ Duration } & \multirow{2}{*}{ Life Cycle } & \multirow{2}{*}{ Longevity } & \multirow{2}{*}{ Life span } \\
\hline & & Larva & Protonymph & Deutonymph & & & \\
\hline $15 \curvearrowright$ & $5.15^{a} \pm 0.29$ & $4.58^{\mathrm{a}} \pm 0.41$ & $5.85^{\mathrm{a}} \pm 0$ & $3.75^{a} \pm 0.44$ & $19.33^{\mathrm{a}} \pm 0.83$ & $37.26^{\mathrm{a}} \pm 1.48$ & $56.59^{a} \pm 2.95$ \\
\hline q & $5.75^{a} \pm 0.46$ & $6.95^{a} \pm 0.66$ & $5.58^{\mathrm{a}} \pm 0.57$ & $4.43^{a} \pm 0.35$ & $22.7^{\mathrm{a}} \pm 0.95$ & $42.38^{a} \pm 1.65$ & $65.08^{a} \pm 3.55$ \\
\hline $20 \pi$ & $3.7^{b} \pm 0.26$ & $4.23^{b} \pm 0.29$ & $5.03^{b} \pm 0.25$ & $3.5^{\mathrm{a}} \pm 0.33$ & $16.45^{b} \pm 0.54$ & $30.4^{\mathrm{b}} \pm 2.1$ & $46.85^{\mathrm{b}} \pm 1.18$ \\
\hline & $4.63^{b} \pm 0.34$ & $4.43^{b} \pm 0.57$ & $5.28^{\mathrm{a}} \pm 0.45$ & $3.9^{\mathrm{b}} \pm 0.34$ & $18.03^{\mathrm{b}} \pm 1.04$ & $32.91^{\mathrm{c}} \pm 1.43$ & $50.94^{\mathrm{b}} \pm 1.85$ \\
\hline $25 \lesssim$ & $3.3^{c} \pm 0.39$ & $4.1^{b} \pm 0.28$ & $3.4^{\mathrm{c}} \pm 0.27$ & $2.55^{\mathrm{b}} \pm 0.31$ & $13.33^{c} \pm 0.59$ & $24^{c} \pm 2.67$ & $37.33^{c} \pm 1.8$ \\
\hline ๆ & $3.6^{c} \pm 0.31$ & $4.4^{b} \pm 0.32$ & $4.25^{b} \pm 0.42$ & $2.75^{\mathrm{c}} \pm 0.21$ & $15^{c} \pm 0.68$ & $29.9^{b} \pm 2.85$ & $44.9^{c} \pm 2.38$ \\
\hline Sig. & $* * *$ & $* * *$ & $* * *$ & $* * *$ & $* * *$ & $* * *$ & $* * *$ \\
\hline
\end{tabular}

Means with different superscripts in the same row differ significantly $(\mathrm{P}<0.05) . * *=\mathrm{P}<0.01, *=\mathrm{P}<0.05$ and $\mathrm{n} . \mathrm{s}=\mathrm{Not}$

Table (7): Effect of temperature on the red palm mite, Raoiella indica Pre-oviposition ,Oviposition and Post-oviposition periods

\begin{tabular}{|c|c|c|c|c|c|}
\hline \multirow{2}{*}{$\begin{array}{c}\text { Different } \\
\text { temps }\end{array}$} & \multicolumn{3}{|c|}{ Duration in days } & \multicolumn{2}{c|}{ No. of deposited eggs } \\
\cline { 2 - 5 } & Pre-oviposition & Oviposition & Post-oviposition & Fecundity & Daily rate \\
\hline $15 \pm 2^{\circ} \mathrm{C}$ & & & & $96^{\mathrm{a}} \pm 7.37$ & $3.41 \pm 0.25$ \\
\hline $20 \pm 2^{\circ} \mathrm{C}$ & $6.13^{\mathrm{c}} \pm 0.36$ & $17.8^{\mathrm{b}} \pm 1.14$ & $8.98^{\mathrm{b}} 8 \pm 0.32$ & $76.9^{\mathrm{b}} \pm 6.28$ & $4.33 \pm 0.36$ \\
\hline $25 \pm 2^{\circ} \mathrm{C}$ & $3.8^{\mathrm{b}} \pm 0.79$ & $17.9^{\mathrm{b}} \pm 1.66$ & $8.1^{\mathrm{a}} \pm 1.66$ & $45^{\mathrm{c}} \pm 6.32$ & $1.49 \pm 2.48$ \\
\hline
\end{tabular}

Table(8):Life table parameters of Raoiella indica (Hirst) females at three different temperatures \& $60 \pm 5 \%$ R.H.

\begin{tabular}{|c|c|c|c|}
\hline Prey species & $15 \pm 2^{\circ} \mathrm{C}$ & $20 \pm 2^{\circ} \mathrm{C}$ & $25 \pm 2^{\circ} \mathrm{C}$ \\
\hline Mean generation time $\left(\mathrm{T}_{\mathrm{c}}\right)^{\mathrm{a}}$ & 32.3 & 23.71 & 20.95 \\
\hline Doubling time $(\mathrm{DT})^{\mathrm{a}}$ & 6.05 & 4.65 & 4.83 \\
\hline Net reproductive rate $\left(R_{o}\right)^{b}$ & 40.55 & 34.96 & 20.29 \\
\hline Intrinsic rate of increase $\left(\mathrm{r}_{\mathrm{m}}\right)^{\mathrm{c}}$ & 0.115 & 0.149 & 0.144 \\
\hline Finite rate of increase $(\lambda)$ & 1.12 & 1.16 & 1.15 \\
\hline Gross reproduction rate (GRR) & 56.61 & 49.3 & 32.31 \\
\hline
\end{tabular}

${ }^{\mathrm{a}}$ Days ${ }^{\mathrm{b}}$ per generation and ${ }^{\mathrm{c}}$ Individuals/female/ day 

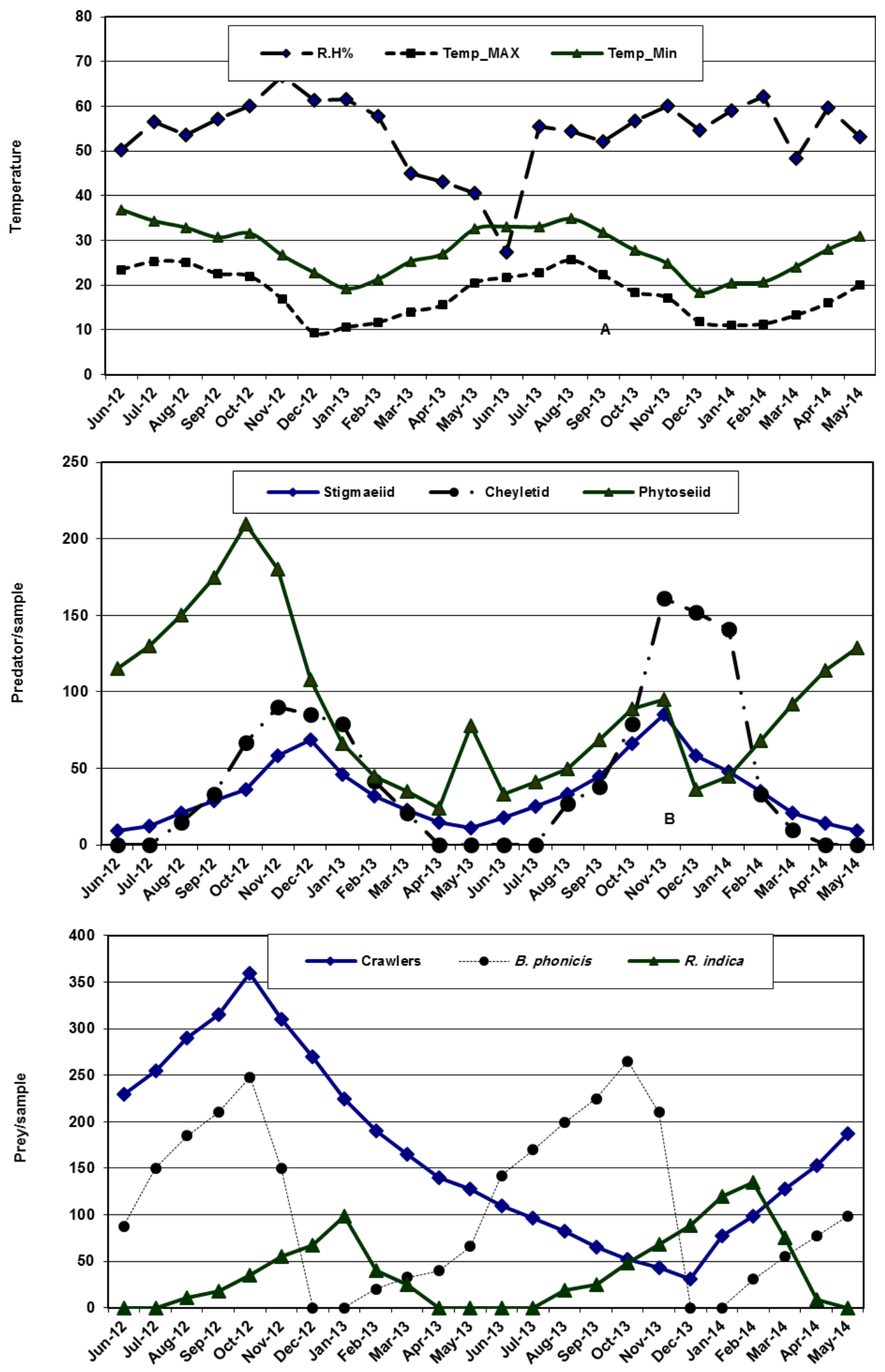

Fig. (1): (A,B,C):-Population dynamics of phytophagous mites and Predators associated with date palm leaves at Sharkia governorate during 2012-14. 


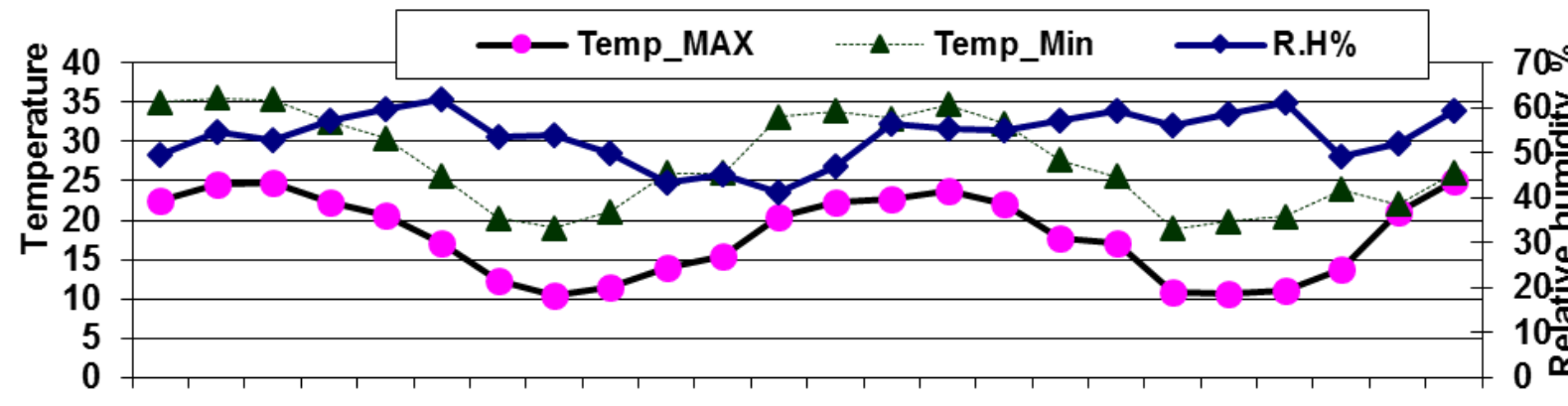

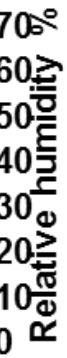

$\lambda^{2} \lambda^{2} \lambda^{2} \lambda^{2} \lambda^{2} \lambda^{2} \lambda^{2} \lambda^{3} \lambda^{3} \lambda^{3} \lambda^{3} \lambda^{3} \lambda^{3} \lambda^{3} \lambda^{3} \lambda^{3} \lambda^{3} \lambda^{3} \lambda^{3} \lambda^{\Delta} \lambda^{\Delta} \lambda^{\Delta} \lambda^{\Delta} \lambda^{\Delta}$

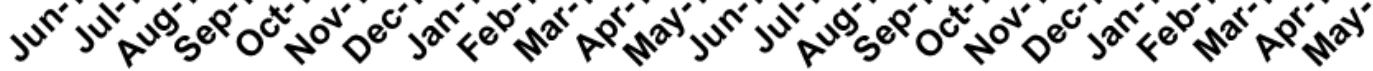
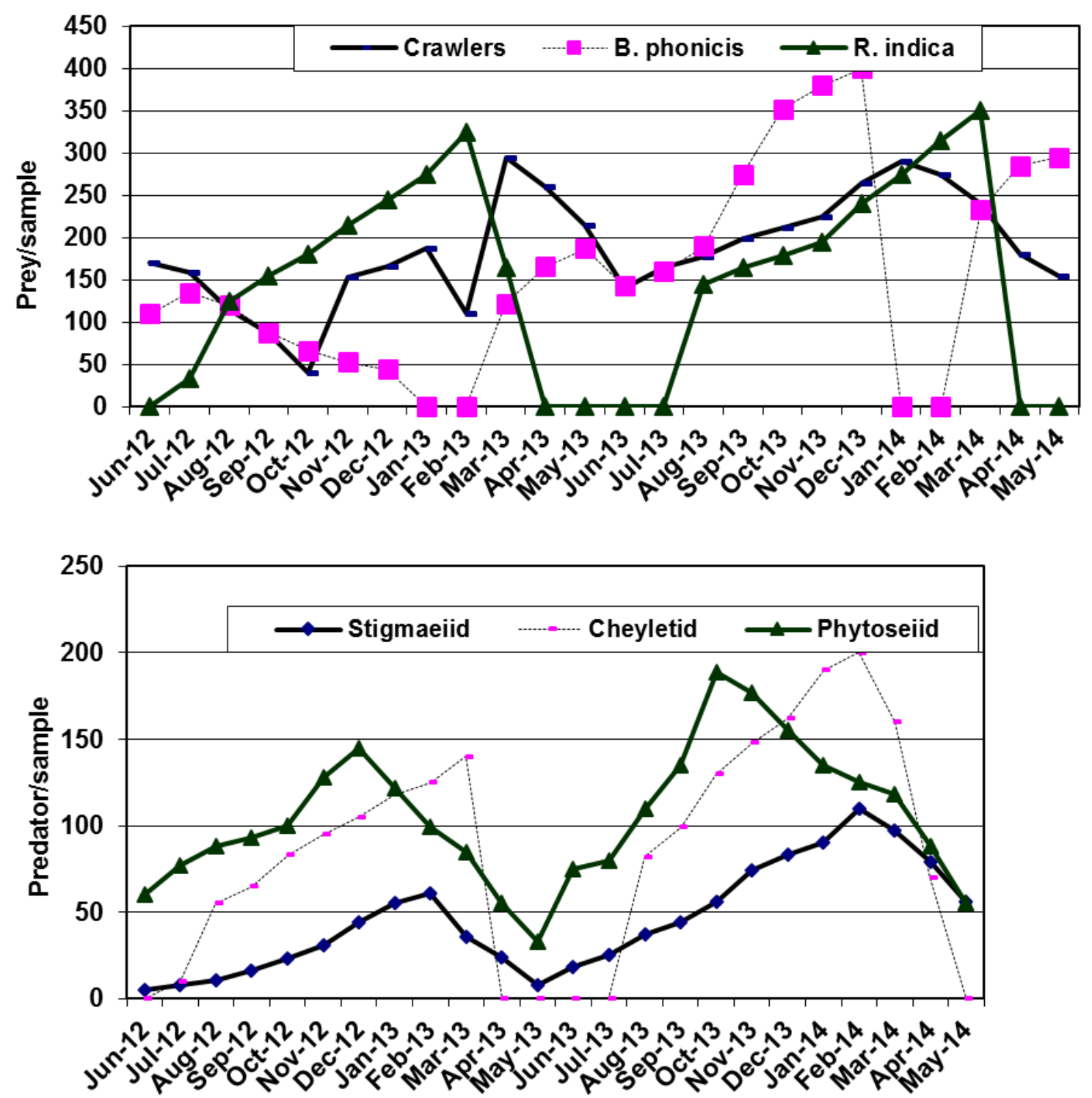

Fig. (2): (D,E\&F):-Population dynamics of phytophagous mites and predators associated with date palm leaves at Giza governorate during 2012-14. 
was found in high numbers in Giza.

Hemicheyletia bakeri (Ehara) was found on leaves in low numbers at Sharkia.

Eutogens africaus (Wafaa \& Soliman) was found in low numbers on leaves at Giza \&Sharkia.

\section{(3) Miscellaneous mites}

During this study, eight species belonging to seven genera in six families were recorded (Table 3).

Family Tarsonemidae: Tarsonemus stiffer (Ewing), T. $\quad$ gladifer (Mahunka) and Stenotarsonemus spirifix (March) were recorded in high numbers from leaves and stored dates in different localities of date palm trees.

Family Tydidae Kramer: Orthotydeus californicus (Banks) was found in moderate numbers on leaves in the two governorates.

FamilyAcaridae Leach: Tyrophagous putrescentiae (McGregor) was recorded in moderate number on leaves and soil in Sharkia.

Family-Glycyphagidae: only one female Blomia freemani (Hughes) was found on fallen date.

Family_Oppiidae \& Orbatulidae: Oppia sticta (Popp) and Zygoribtula sp were found on fallen date in low numbers.

Twelve species of predatory mites in eight families have been reported in our research in association with $R$. indica and other phytophagous mites in the two governorates.

Similar results were obtained by, El-Halawany et al. (2001) who collected 16 species of mites belonging to 11 families and classified according to their feeding habits to 7 species plant feeders, 6 species predacious and 3 species of miscellaneous feeding habits. Sallam and Yassin (2005) found 36 different mite species belonging to 33 genera of 18 families associated with date palm at El-Wahat ElBaharia Oasis, Egypt.

Carrillio et al. (2012) reported sixteen predacious mite species belonging to six families in two orders in association with $R$. indica. AL-Jboory and Saleh (2001) surveyed mites living on date palm trees in Iraq during 2000 and 2001, revealed that 26 mite families containing 34 genera were collected. Majidi and Akrami (2013) surveyed mites inhabiting date palms (soil, leaves, fruits and trunk fibers) during 2009-2011and found 56 species belonging to 47 genera and 34 families.

\section{II-Population Dynamics}

Population dynamics of different mites associated with leaves of date-palm at Sharkia and Giza governorates during 2012 and 2013 years are illustrated in Figs.(1 \& 2). Correlation between population densities of studied mites and weather factors at both governorates over the two years of study are presented in Tables $(4 \& 5)$.

1-Sharkia location: An increase in phytoseiid predator density was observed when population of crawlers of the scale insect Parlatoria blanchardii (Targ.) and Brevipalpus phoenicis (Geijskes) increased $(\mathrm{r}=0.873 * * * \& 0.921 * * *)$. Numbers of cheyletids and stigmaeids increased when $R$. indica populations increased especially with effect of temperature during the first year of study.

Statistical analysis results of Raoiella indica (Hirst) revealed high significant correlation between $R$. indic $a$ and each of cheyletid and stigmaeid mites ( $\mathrm{r}$ $\left.=0.899 * * * \& 0.851^{* * *}\right)$, while highly negative significant correlation with maximum and minimum températures $(\mathrm{r}=-0.802 * * \quad \& \quad-0.722 * *)$ and $(-$ $0.897 * * * \&-0.843 * * *)$ with population density of $R$. indica during the two successive years. However, relative humidity had positive correlation with mite population. The phytoseiid mites have non significant correlation affected on $R$. indica during the two successive years. While the cheyletid and stigmaeid mites had possitive affected on $R$. indica in the first year, while in the second year the stigmaeid mite nonsignificant positive affected on the $R$. indica.

Statistical analysis results of $B$. phoenicis and crawlers of scale insect:-

The tenuipalpid mite $B$. phoenicis population was significant positively correlated with temperature during the two successive years, but non-significant correlation between density of tenuipalpid mite and relative humidity, in the first year it was positive and in the second year it was negative.

The crawlers of scale insect, population had nonsignificant positive correlated with temperature during the two successive years, while highly positive correlation between density of $P$. blanchardii and relative humidity in the first year and non-significant negative correlated with population in the second year.

The phytoseiid mites seemed to be an important predators to suppress the population density of $B$. phoenicis and scale insect population. However the cheyletid mites affected on,$R$. indica population during the two successive years $(0.899 * * * \& 0.610 *)$, respectively.

\section{2-Giza location:}

An increase in cheyletid predator density was observed following decrease in the $R$. indica then numbers of cheyletid predators were still consistently low. Starting in April, there is normally a decline in 
populations, which continues through July Cheyletids appeared in the same months from August till march with high numbers and the stigmaeid mites also occurred with high fluctuation densities that's gave importance for using predatory mites to control phytophagous mites. Several predators were found on the leaflets of date-palm preying on phytophagous mites. This agrees with, Mesbah and Omar (2014) showed high ability of the cheyletid mite, Cheletogens ornatus to suppress eggs and immature of R.indica populations on date palms. and Carrillio et al(2012) who reviwed all phytoseiid predators that can manage $R$. indica and observed Hemicheyletia bakeri Ehara feeding upon all stages of $R$. indica in Iran.

\section{B-(I)-Statistical analysis of $R$.indica results:-}

The correlation coefficient showed high significance between $R$. indica and the cheyletid predators $(\mathrm{r}=0.919 * * * \quad \& 0.932 *)$ during first and second years, respectively. It showed also high significant correlation between each of phytoseiid \&stigmaid predators $(0.836 \& 0.868)$, respectively in the first year.

On the other hand, statistical analysis of $B$. phoenicis (Geijskes) results showed negative high siginificant correlation with stigmaeid; phytoseiid \& cheyletid mites $\left(\mathrm{r}=-0.795^{* * *} ;-0.826^{* * *} \&-0.759^{* *}\right)$ and very low significant differences with minimum temperature.

Also, statistical analysis of scale insect, $P$. blanchardii there were negative nonsignificant difference between predators and scale insect during first year while in the second year it showed high significant difference between cheyletid $\left(0.953^{* * *}\right)$ and stigmaid $\left(0.835^{* * *}\right)$ predators.

Obtained results are in agreement with Taylor $e t$ al. (2011) and Vásquez and Moraes (2013) whom studied the seasonal fluctuation of the population of $R$. indica and associated mite species with reference to weather parameters and predator mites.

$R$. indica are generally abundant on date palm leaves from Aug. to Feb. Starting Mar., there is normally decline in populations, which continues through July. The lower leaves had high infestations ranging from 150-350 individuals. population of $R$. indica increased in Giza governorate was from 100350 individual than in Sharkia Governorate (20-135) individual and in the second year than in first year of study. All of these results agree with finding of Pena et al., (2006) and Kane and Ochoa (2006).

Etienne and Fletchmann (2006) found $R$. indica infesting palms and Welbourn (2006) indicates that,
$R$. indica dispersed by wind currents and transport of infested plants or leaves.

\section{III-Biological studies}

The present study was conducted to evaluate the effect of constant temperature on $R$. indica developmental life stages in days, life cycle, adult longevity, female fecundity and life-span.

Because of the importance of the date fruits as one of the "main crops in Egypt, it was found necessary to throw light on the biology of acarine pests before carrying out any control program, Zaher et al., 1969; who carried out biological studies on the red palm, $R$. indica infesting date palm trees.

Incubation period:- Egg incubation period of R.indica was 3.6 days at $25^{\circ} \mathrm{C}$ while it were $(5.75$ $\& 4.63$ ) days at $15 \& 20^{\circ} \mathbf{C}$,respectively ; Table, 6 .

Life cycle:-The mean developmental period from egg to adult (life cycle) was significantly influenced by temperature, $\mathrm{RH}$ and host plant.Female life cycle were $(22.7 ; 18.03 \& 15)$ days while male life cycle were $(19.33 ; 16.45 \& 13.33)$ days, at $15,20,25^{\circ} \mathrm{C}$, respectively.

Therefore, the earlier results showed that the developmental time of $R$. indica was significantly affected by different temperature and lasted (65.08, $50.94 ; 44.9)$ days and $(56.59,46.85 ; 37.33)$ days during its life span, for females and males, respectively.

Therefore, feeding at $15 \pm 2^{\circ} \mathrm{C}$ significantly prolonged predator longevity (42.38 \& 37.26 days), for females\& males, respectively and caused a higher rate of fertility averaged (96 egg) through an average oviposition period of 28 day.

Pre-oviposition period averaged 6.6 days in winter at $15{ }^{\circ} \mathrm{C}$ and 6.13 days at $20^{\circ} \mathrm{C}$ and 3.8 days at $25^{\circ} \mathrm{C}$ in summer seasons. This agreed with, Jepson et al., 1975, who noticed that preoviposition period was 3 days in summer and 7 days during winter.

Pena et al., (2006) studied the biology of $R$. indica at temperatures between $24-26^{\circ} \mathrm{C}$ and $60 \% \mathrm{RH}$, females completed their development in 24.5 days and males in 20.6 days; adult longevity was 50.9 days for females and 21.6 days for males. Fertilized females produced an average of 22 eggs and virgin females 18.4 eggs. Females lay an average of 2 eggs per day over an average oviposition period of 27 days for a total of about 50 eggs per female. The time for development of each life stage is: egg, 6.1-6.5 days; larva, 5.7-9.5 days; protonymph, 5.4-6.5 days; and deutonymph 4.1-10.5 days. The time required to 
complete the life cycle is 21-33 days.

Galano et al. (2010) studied the development and reproduction of $R$. indica on Areca catechu under laboratory conditions at $25,42 \pm 1,21^{\circ} \mathrm{C}$ and $57,54 \pm$ $6,54 \%$ R.H. The experimental units were leaf discs of A. catechu in Petri dishes (10.5 cm diameter) with water-saturated cotton. Gravid females were transferred to experimental unit and allowed to lay eggs for five hours. The duration of each life cycle stages were registered. The larvae that emerged were transferred to individual arenas and observed until adult appearance. The average duration of the life cycle was 31 days. The egg stage was the longest, while that of protonymphs was the shortest. The preoviposition period averaged 4 days, while the oviposition period can last 17 days, with an average of 11 days and a female longevity of 30 days. Sex ratio was $56 \%$ females. The mortality of immature stages was: $14,6 \%$ for larvae; 7,3\% for protonymphs, and $17,1 \%$ for deutonymphs, with $39 \%$ total mortality.

In order to develop an efficient method to rear the Red Palm Mite in quarantine for a classical biological control project, several banana and plantain varieties were tested as hosts for the RPM. Bananas are more desirable than coconut (a favored host plant) because bananas are easier to rear in small cages and will produce new shoots quickly after pruning, Cocco and Hoy (2009).

\section{IIII-Life table parameters}

The mean generation time (T) of $R$. indica was significantly affected by temperature (Table 8 ). Its life table parameters were as follow, ( $\mathrm{T}$ as 32.31; 23.71 and 20.95 days); net reproductive rate $\left(\mathrm{R}_{\mathrm{o}}\right)$ $(40.55 ; 34.96$ and 20.29$)$ per generation; intrinsic rate of natural increase ( $\mathrm{r}_{\mathrm{m}}$ as $0.115 ; 0.149$ and 0.144$)$; finite rate of increase $(\lambda)$ averaged $(1.12,1.16$ and 1.15 ) and gross reproductive rate (GRR) (57.29; 49.3 and 32.56 ) and doubling time (DT) values (6.05; 4.65 and 4.83$)$ days when females reared on different temps (Table 8), respectively.

It can be concluded that no single factor is responsible for phytophagous mite population but all the factors work in compliment with each other. Therefore, it is suggested that climatic weather factors with predator mites should be considered before using any way of IPM-Programs for harmful pests.

\section{ACKNOWLEDGEMENTS}

We like to thank Prof. Dr. M.E.El-Naggar, who suggested the plan of this study and continous support. Thanks are also to Prof. Dr. M. M.
Abou-Setta for revision and criticizing the statistical analysis of data.

\section{REFERENCES}

AL-Jboory, I.J and Saleh,S.J (2001). Survey and taxonomy of mites inhabiting date palm trees in Iraq with some observations on the parasites of date palm stem borders . Barsa Date Palm Research Journal.Vol,(1)No,(2),5pp.

Carrillo,D, Frank,J.H, Rodrigues,J.C and Pena,J.A (2012).A review of the natural enemies of the red palm mite, Raoiella indica (Acari: Tenuipalpidae). Experimental and Applied Acarology ,Volume 57, Issue 3-4, 347-360

Carrillo,D; Hoy, M.A and. Peña,J.A(2014).Effect of Amblyseius largoensis(Acari:Phytoseiidae) on Raoiella indica (Acari: Tenuipalpidae)by predator exclusion and predator release.Florida Entomologist 97(1) March 2014.

Cocco, A. B. K and Hoy, M. A. (2009). Feeding, reproduction, and development of the Red Palm Mite (Acari: Tenuipalpidae) on selected palms and banana cultivars in quarantine.Florida Entomologist.Vol,92:276-291.

El-Halawany, M.E., Abdel-Samad, M.A. and ElNaggar, M.E. (2001). Mites inhabiting date palms. In Second Inter. Conf. on Date Palms (Al-Ain, UAE, March 25-27, 366-373.

El-Sanady,M.A and Mohamed,A.A(2013).Biodiversity and Seasonal abundance of mites associated with two varieties of date palm in Giza and Sohag Governorates,Egypt.Acarines, 7(2):57-62.

Etienne, J., and Flechtmann, C. H. W. (2006). First record of Raoiella indica (Hirst, 1924) (Acari: Tenuipalpidae) in Guadeloupe and Saint Martin, West Indies. Int. J. Acarol. 32: 331-332.

Galano,G.F. ,Montoya, A and Rodríguez.H(2010).Biology of Raoiella indica Hirst (Acari: Tenuipalpidae) on Areca catechu 1.Revista de Protección Vegetal vol,25 No,(1), 17pp.

Jepson, L. R., H. Keifer, and E. W. Baker. (1975).Mites injurious to economic plants., University ofCalifornia Press, Berkeley, 614 pp.

Kane, E., and R. Ochoa. (2006). Detection and identification of the red palm mite Raoiella indica Hirst (Acari:Tenuipalpidae). USDA, ARS, Beltsville, MD, 6 pp.

Majidi ,M and Akrami, M.A (2013). Mites associated with the date palm (Phoenix dactylifera L.) in Larestan (Fars province), southern Iran .Persian Journal of Acarology, Vol. 2, No. 2, pp. 335-339. Mesbah, A.E and Omar, N.A (2014).Predator-prey 
preferences and Life-Table-Parameters of Cheletogens.ornatus(C\&F)toRPM,Raoiella.indic $a$ HirstandDateScaleInsect,Parlatoria.blanchardii (Targ.)(Acari:Cheyletidae:Tenuipalpidae).Acarin es.Vol,(8)NO,(2). Accepted,June2013(Under press).

Pena, J. E.; Mannion, C. M.; Howard, F. W. and Hoy, M. A.(2006). Raoiella indica (prostigmata Tenuipalpidae): The Red palm Mite: A potential invasive pest of palms and Bananas and other Tropical crops of Florida. UF. University of Florida,8pp.

Sallam,G.M and Yassin,E.M.A (2005).Survey of mites and spiders associated with date palm at El Wahat El Baharia Oasis.Minufiya .J,Agric. Res.30(6):1843-1851.

Sallam,G.M.; Yassin,E.M.A and Abd ElAzeim,N.A (2007).The predatory insects, mites and spiders associated with date palm pests in Rashid region
,ElBeheira

Governorate,Egypt.J.Agric.Res.,85(1),37-51.

Taylor B, Rahman PM, Murphy ST and Sudheendrakumar VV (2011). Within-season dynamics of red palm mite (Raoiella indica) and phytoseiid predators on two host palm species in south-west India. Exp Appl. Acarol.

Vásquez, C and Moraes,G.I(2013). Geographic distribution and host plants of Raoiella indica and associated mite species in northern Venezuela. Exp Applied Acarology. vol, 60:73-82

Welbourn, C. (2006). Red Palm Mite Raoiella indica (Acari: Tenuipalpidae).Pest Alert. DPI-FDACS; 4pp.

Zaher, M. A. A.; A. K. Wafa and A. A. Yousef (1969). Biological studies on Raoiella indiea Hirst and phyllotetranychus aegyptiacus sayed infesting date palm trees in U.A.R. (Acarina: Tenuipalpidae) Z. Angew. Entomol. 63; 406-411. 